\title{
On Storytelling, Teaching, Chance, and Gratitude: In Conversation with Alphonso Lingis
}

\author{
Tone Saevi, NLA University College, Bergen, Norway \\ tone.saevi@,nla.no
}

Patrick Howard, Cape Breton University, Canada

Patrick.howard@cbu.ca

\section{Introduction}

Alphonso Lingis has moved philosophy and phenomenology in unique and innovative directions. His life work may be considered disruptive. His writing and subject matter have pushed boundaries to result in a body of work that reveals meaningful glimpses of human subjectivity and corporeality in relation to a living, sensible world of others. He is a philosopher-explorer describing individuals and cultures in ways that expand Levinasian notions of alterity and Merleau-Ponty's phenomenology of the lived body. Through Lingis' travels we move into deeper and wider contact with the world.

In this Special Issue, we are pleased to present an interview conducted with Alphonso Lingis by Phenomenology \& Practice main editor Tone Saevi. The two met in London, and over several hours, Professor Lingis generously shared his thoughts on a wide range of topics. And in true Lingisian fashion, a lot of ground was covered.

Through his memories, stories, and insights, we enter into more inclusive realms of otherness and build a sense of commonality and belonging with others. It is through Lingis' attunement to embodiment, sensuality, and affect that the world is understood differently. We are called to be attentive, attuned, and aware with a well-developed capacity to demonstrate concern and a desire to act in a manner that reflects our affinity and affiliation with others in a larger living world that is truly wondrous.

TS:

It's a pleasure to meet you. Meeting you is the most important thing. I was thinking of hundreds of questions, but I decided to focus on small things. I really would like to know who you are; but in the way you write it's not who you are that is the point, but it is how you are who you are. So I would like to know a little bit more about you.

AL: $\quad$ My parents were immigrants from Lithuania. They came separately and met in the United States. My father had no formal education; I think when I was a boy I was very impressed by that. Their message was that they were very poor. Lithuania was terribly poor. But they did well as farmers in America. 
TS:

AL:

TS:

AL:

TS:

AL:
Just outside of Chicago?

Yes.

I had, especially in adolescence, a conflictual relationship with my father. But I think somehow I got the idea that I could do anything from my father, who had no education and really no connections when he came. I think he came with one friend. He was young when he came; he was escaping the Tsarist draft in Lithuania. The oldest son would be drafted into the Tsarist army for twenty-five years. He escaped by hiding in a hay wagon to get into East Prussia. When he arrived in America, he worked in factories. Then there was a depression, and he worked for a year on a farm with no salary. So I had this model of someone having no advantages but doing well. Then I did well in school. So I think I had an idea that I could do anything I wanted.

I decided to leave the farm and go to university and then to Europe to study in Belgium. After that, I wanted to see the world. Every year I would just decide on a whim where to go in Africa or Asia or South America. With my salary it was possible, especially if you go outside of Europe and the United States; the rest of the world is inexpensive to us.

I got a job fairly easily. I was a student in Belgium and wrote letters to get at my first job--at Duquesne University in Pittsburgh. They gave me good courses to teach. After six years I got invited to the Pennsylvania State University. I wasn't looking for a job and never understood how they heard of me, as I hadn't published anything. So somehow, professionally, I was lucky.

Yes, that is a very good start.

For a long time, I didn't publish at Penn State either. When I was a student, the philosophers were Bertrand Russell and Heidegger, and so for a long time I didn't feel that I had anything to say; I thought I was still learning. I enjoyed teaching very much because I was learning things. Then I started publishing a few things that were not so academic.

What kind of things?

Since I was a boy, I wanted to go to India and finally went in 1974. I went to Khajuraho that has, I think, twenty-two wonderful temples covered with extraordinary erotic carvings--thousands of them. They are made of very hard granite and are in magnificent condition. I thought they are about the most marvellous things that my eyes had been given to see! I had never heard of them before I went to India but now thought that they are as great as the sculpture of ancient Greece. I stayed there two weeks and tried to read everything I could in any language I could read about these temples. I was disappointed in what I read. I thought that out of gratitude, maybe after I retire, I would go there and spend a long time with these temples and then maybe write about them. When I came back to the US that year, I was invited to a small meeting, and they 
TS:

said I could talk about whatever. I thought, "I wonder if I could write something about those temples?" I wrote a little piece about them; I had not arrived at a big understanding of them, but I felt it was something.

AL:

Yes, it was your own?

I was pleased that I was able to write something truthful about the temples. That made me think that from then on, every time something moved me deeply, I should write about it. And I began to think of writing in terms of gratitude. Gratitude is a sort of action. If somebody arrives at your house and gives you a bottle of wine, you first take it, hold it, look at its colour, and then open it and pour it to your guests; the last glass is for you. I thought that when something is given, as the vision of those temples was given to me, I wanted to hold it, and one way of holding it is writing about it. And to write about it is to share it.

I used to like to write letters a lot. In a letter, I would try to write well, because the idea is to actually share something you experienced. You don't just say, I went to the Grand Canyon, and it was great. You have to use the resources of language to try to give someone something of the experience that you had. Many of these writings started as letters and then became essays or sometimes became talks and then eventually got collected in books. These books are not very academic in form. I also wrote some academic books, so my position was never in danger. I think that my academic career happened easily and that I was lucky.

TS:

It is a very phenomenological way of doing things, isn't it? You address this building or this animal or this person and you share it with somebody, you describe it, you understand it. That is why I am so fascinated with your writing. For instance, I just read your paper on the plane about a jellyfish, the transparent jellyfish. I've never seen one like that but you help me in a way to come a little bit closer to it and at least to want to see it.

AL: $\quad$ I would always leave as soon as the last class was finished. I went to some other country but didn't go with an academic project; I just wanted to see the world. But I think there was always a connection between philosophy and anything else I did. I think that philosophy and particularly phenomenology helped me understand what I saw about me. Heidegger's essay "Origin of the Work of Art" helped me to understand temples. If an object or a person or a situation or a tragic event moved me, I was always helped to deepen my understanding by philosophy. On the other hand, going to other countries broadened the expanse of the world and captivated me more and more.

TS:

But you have seen many things that are not so easy to see, to have seen?

AL:

Yes, that's true. I was in Calcutta during the 1971 Bangladesh war. There were at least a million refugees in Calcutta; they people were sleeping on the sidewalks. The night before I left, I went for a walk. It was raining a little, and families were just lying on the sidewalk in the rain outside 
my hotel window. I remember returning to my room shaking with tears. I had been in Calcutta two months and had often seen that, but that night I was shaken all over again. I slept on the bed knowing that every night right outside the window there were families sleeping on the sidewalk. You cannot feel justified. And I don't think that it is a good thing to try to justify oneself. The only thing is that it doesn't change anything if you don't go to such places. If I sleep in my bed in America, now that I know there are those people sleeping on the sidewalk in Calcutta, I have not become more ethical by not being there.

If you don't see or know these things you can skim over reality and not really live in the real world.

TS:

There is a photo in the book The Community of Those Who Have Nothing in Common. There is a photo of a young boy; it's the chapter on torture. He has a number and it was 186, and he is wounded and looks into the camera. It's very strong; it's about torture and truth.

AL: $\quad$ I didn't take the picture of that boy. He was a boy who was executed; the photos were taken by the prison staff.

TS: $\quad$ That is a very, very strong picture, but many of the pictures are of people leading different lives but also suffering somehow. I was thinking, do you know the people you take photos of? Do you have a relationship with them?

AL:

There's always a minimal relationship. When I started I didn't like taking pictures. I didn't like the image of the tourist with the heavy camera. More than that, I thought there was something false about trying to retain the past. That what you retain is what changes your life.

I got a camera quite accidentally. A friend who was a camera enthusiast was taking me to the airport and on the way stopped to pick up his new camera. He gave me his old one. It was my first trip to India. At first I only took pictures of landscapes and buildings because I thought it was intrusive to photograph people. Then one day I was on a boat in Dal Lake in Kashmir at the end of the day and was taking a picture of willow trees along the edge of the lake. Suddenly I saw that there were men bathing there and in embarrassment I put down the camera. They saw me--and waved and said thank you!

TS:

They wanted you to take photos of them?

AL:

I realised they were pleased and flattered.

At that time I was trying to learn how to take photos. In every town you could develop black and white film. As soon as I finished taking a roll of film, I would develop it and criticise the photos. Then I always took the picture back to give to the person. I discovered that it was like the best gift I could give them. People so poor they could never afford to have a photograph. If I gave them a little money, it's not so meaningful. 
TS:

And it was also the self; this is me, you see me. So, you went searching for the poor people to give them their photograph?

AL:

Yes. Then I would also photograph their family, their grandmother or children. I saw that for them to have a photograph of their family is precious. Usually you can find a poor person whose photo you took; he will be there tomorrow, or if not there will be people who know him and you could give someone the photograph. Sometimes when I was leaving I could find somebody who could write an address, and I would send the photograph later.

Sometimes I took pictures of people from a distance, but there was always a small meeting even if it only lasted a few minutes. It became a way for me to make contact with people. People understood that I am a rich person who came from the other side of the world and am not interested in the rich people of India or in palaces but in people, ordinary people. I think there was always something of that idea there, which they were pleased with. Children always loved to be photographed. With women there is sometimes a matter of cultural modesty; many women did not want to be photographed by strangers.

TS:

I'm thinking of you as a storyteller, and I think actually that's maybe a very common word, and it doesn't describe you well enough, but it's an honour to be a storyteller. The first time I read your books, the first book was The Community of Those who have Nothing in Common and what spoke to me, what touched me then was your stories and of course the stories the pictures told. How do you understand storytelling as a part of not only being a philosopher, but being a human being?

AL: $\quad$ It's only recently that I began thinking about the stories. I was struck that everybody has a story.

The one time I wanted to tell someone's story was the story of the two junkies in a prison in Australia, dying of AIDs. My last night in Australia two people I had met invited me to dinner. A woman arrived later whom I didn't know. She said she was an artist. I started asking her about her work. She said that she volunteers teaching a course in art in the maximum-security prison. I wanted to know about that. Then she told me the story of two junkies.

When Cheryl, one of the junkies, got released, they issued her a small amount of money. It was not enough to buy a real gun; she used a perfume bottle under a scarf and went to a McDonalds and said, "This is a hold up; give me two hundred dollars." She pulled this hold-up in order to get rearrested, to die with her lover in a cement cell in prison.

I left Australia. But for weeks I couldn't get this story out of my mind. I thought I had never heard of anyone love somebody that much. I thought these are the most important people in the planet. I had the address of one of the persons at the restaurant that evening; I wrote him and he put 
me in contact with the artist. She assured me that Cheryl and her lover would like to meet me; they would like their story to be known.

I went to Australia three times and tried to meet them. Finally I was able to get permission and was allowed to see them three times for an hour. When I met them, it was so obvious that they were totally in love with one another.

I told their story a number of times in the US and then had an opportunity to tell their story in Sydney, their city, after they were dead. I was pleased to be able to do so. After someone is gone, their story may remain. Not simply as an example for us, but simply, importantly, as a memorial to them.

On the other side, there's the practise of silencing people's stories. Someone can tell his or her story if we listen, but there are people in Africa and Guatemala, the Third World, that no one listens to. Their stories are silenced. The opportunities to tell their stories do not exist.

I'm now thinking about my father. He was a great storyteller. Even in my worst years of adolescence, I always loved it when he would tell some of his stories. Towards the end of his life, I tried to get him to tell his stories more and more. It's something I hear from many friends; I remember a woman, an English major, told me that instead of reading literature she was spending time at her infirm grandmother's bedside, getting her to talk of her life. The granddaughter really wants her story, but the grandmother also wants to give her story to her children and grandchildren.

TS:

Yes stories teach. I am an educator - a pedagogue, and I think about the education of the young, and I think it's hard to educate young people even if you believe in them. What kind of advice would you give me as a teacher that I can give to my students?

AL:

When I finished my graduate work, I didn't think I would go into teaching; I thought I would wash dishes for six months and then write books or something and travel. I took a job teaching because I was in need of money. I remember I was terrified, worried whether I could keep order, whether everybody would laugh and jeer. In fact students look at you with respect and expectation. I was astonished. You don't deserve it, but it continues year after year. I always felt I saw so much expectation of the best in young people. If I could do my best, if I could enlighten them, or as you say, tell stories that are real stories, that are meaningful, there was so much readiness for that.

I hate cynicism, and it seems to me that the cynicism comes to people when they get older. Incompetent teachers are cynical. They go on saying it's all the student's fault: they are so stupid and uninterested. It seemed to me my resolve came from students, their expectation, and idealism.

TS: Do you have any thoughts of what you teach with your writing? 
AL:

TS:

AL:
I didn't think about it too much when I was a teacher. I think in a certain sense I really wasn't teaching.

How so?

If you are teaching geometry, you want to make sure that every student in the class gets every chapter, every day, because if he or she don't get it, he or she won't get what we lay out tomorrow when we move on. And if you don't master geometry, you won't get the next mathematics course. But I think that is not the case in philosophy.

It would occur to me that there were forty thousand students in Penn State and most of them would never take a philosophy class. Most of them would not take my class, so I could never feel that my class was so important.

I would just pick five books on anything that I happened to be interested in. What I wanted to do is entice students to get interested in these issues and think about them, and it seemed to me that if I were very interested in these issues, I would convey interest to them. So I tried to provide an example about how to think in philosophy.

I felt that people picked it up in different degrees. There were students who never said anything the whole semester; when I read their final paper, I found that they had thought most interestingly and most deeply. There are students who prefer not to talk. So I didn't demand that everybody talk: if someone had something to say he or she would say it, but if he or she wanted to be silent that was okay.

What was interesting for me was what I was picking up from the students. I was always getting insights and new angles and ways of thinking from them.

When I retired, I thought I would no longer have contact with young people. But it happens that I get four or five, sometimes six invitations a year, and I end up meeting some young people. Occasionally some of these people stay in contact, even a few of them have visited me later. So I still have contact with young people. I go to conferences and there meet graduate students and young professors.

Sometimes the undergraduates were more interesting than the graduates. Penn State was very selective, so it's only people who have very high grades who are admitted to the graduate program. Often these people had done nothing in their life but read books. I've read those books, so sometimes it was more interesting to talk to undergraduates who have already done other things in life and have done things on their own.

TS:

I'm thinking of new phenomenologists. I'm supervising young students in their doctoral studies and many of them are aspiring phenomenologists. Phenomenology is a way of seeing the world and a way of doing research. Yet that way of researching is not as valued now. 
AL:

It's hard for them to get scholarships. They have a limited time frame to do their doctorate so they do not really want the time to think and to look and to write in that way. How can we open up the phenomenological philosophical world for young people?

I never like to give sermons, so for a long time I wouldn't really talk about it, but finally I began to say this: That if you think that this topic is important enough for you to spend several years of the best years of your life on, then you must think it's important for other people. Consequently it's urgent for you to write in such a way that you communicate, instead of just writing in such a way that people think that you are profound because what you write is obscure. There is this problem that philosophy graduate students have in the United States. You have to write; if you want to keep your position you have to publish. Then you can do a certain amount of trade publishing. You write about the difficult and classical authors, Kant, Hegel, Heidegger, but nobody reads what you write. You settle with making it sound learned and professional. In that way philosophy withdraws from culture and human issues.

I studied in Europe. In France philosophy was popular; if you went to Paris and wanted to hear Foucault, you had to go two or three hours beforehand; otherwise you would be in another room with a loudspeaker in front. Hundreds of people would come. Most of those people will not have jobs in philosophy; maybe they could get jobs in journalism and in publishing houses. I remember hitchhiking and being picked up by a mechanic, and he telling me how much he loved Sartre.

TS:

There is something with phenomenology that I think is really needed now, more than ever needed, but at the same time it is so problematic to do that kind of research, and to live that way because it's not only a way of doing research, it's a way of living, a way of seeing the world.

AL:

A few philosophers have always closely watched cultural developments. It seems to me that philosophical thinking could be extremely helpful in biological research. And cosmological research--these concepts of black holes and space in four dimensions, all those complex constructs they use in astronomy. It seems to me that many of them are very close to philosophical speculation. One doesn't understand why philosophers and specialists in these areas could not usefully work together.

TS:

How can we contribute to that?

AL:

First of all we have to acquire the interest and the mastery of material.

I think very highly of the Australian philosopher Elizabeth Grosz. I heard her read a paper about Siamese twins; it raises the issue of identity, because here you have two people who will share all their sensations.

That makes me remember two German Siamese twins in the circus, thirty years ago in the United States. One of them found a lover; a man was 
very seriously and deeply in love with her and wanted to marry her. The judge refused on the grounds that it would be bigamy.

TS:

Do too many phenomenologists do research within their own narrow fields?

AL:

Yes, too much so. One has to find information and experience whatever it is.

TS:

I think that is what is needed for young people and especially perhaps for young phenomenologists to go and see and when you write about things you must see it for a second or third or fourth time.

AL:

Yes. Sometimes we can look very superficially.

You know I always say yes to everything. Only once or twice did I ever say no to a request; I really cannot write about that. I think I always learn something. Sometimes to be sure I end up writing something that's not very good.

The last thing somebody wanted to write about was pilgrimage and travel. I went back to something that I did want to talk about. Twice I went to Argentina and rented a car. In the west of the country under the Andes mountains I began to see shrines everywhere, every five kilometres along the road. Eventually I ended up at the main shrine. I learned that somewhere around 1850 during one of the country's civil wars, a young man was taken away to join the army of a warlord. Later his wife learned that he was ill; she took their baby and went out to join him. It was sixty kilometres across desert. She lost her way and died of thirst and exposure. About forty years later a herdsman was driving cattle over the area. There was sudden storm and the cattle were dispersed in panic. The herdsman happened to be at the grave of this woman; he implored her help. He found all his cattle. He built a little shrine over her grave. It wasn't until around 1940, almost a hundred years after her death, that the grave and shrine become important.

People passing through the desert with cattle would leave an offering at her grave, often bottles of water, and implore her help. Around 1940 the story crystallised that when she was found dead her baby was alive, nursing at her breast. The devotion becomes really big. Truck drivers began revering and imploring her and building little shrines all along the roads, putting bottles of water there. I discovered this about fifteen years ago, and I went back about five years ago and I was astonished to discover the devotion is now bigger still.

The woman's name was Correa, and she's revered as the Difunta Correa, the deceased Correa, but nothing really is known about her. All they know is that she was a young woman who had a baby. Whether she was virtuous or not is not important. In fact, one of the stories was that the baby's father was not by Correa's husband but the local policeman. 
The ex-votos and gifts to the shrine commemorate milagros. Milagro is translated miracles, but they are more what we would call favours. A driver who manages to drive a long distance without mishap would given an ex-voto to the shrine for the favour. The shrines are full of homemade statues and paintings, all folk work. It's not just poor people; people who got admitted to universities in America thank Difunta Correa for this favour; there are doctors who've given her their medical degrees. When you break your arm, and it heals, it is not exactly a miracle; it's not against the laws of nature. But I understood that these people live in is a world not integrally governed by laws, a world of chance.

One day long ago In India, in the place where the Buddha preached his first sermon, I met an astrologer. He told me there are three things; there is necessity--and we have a discourse about necessity: the natural sciences. There is choice--we have a discourse about choice: ethics and politics. But there is also chance. Nowadays we don't have a respectable discourse about chance; there is just the horoscope column in the newspaper.

He left a deep impression on me. I began to think that the most important things that determine our life happen by chance. It's chance that this particular sperm met this ovum and I got born; it's chance that I get born without physical defects; it's chance that I get sick, get into an accident, get a disease; it's chance that I met the true love of my life; it's chance that I got a position or didn't; and it's chance the way I die, in an accident or with a disease or by something for which I cannot assign fault or a cause. It seems to me that the people of Argentina have a vivid sense of chance--that when you go on an airplane it's by luck there will be no accident.

I started by being struck by this strange modern devotion to Difunta Correa, and then I began to think that really there is an ontological world that involves chance that they live in. And that the consciousness of chance is gratitude. I feel grateful that by good luck I got safely to my destination. If I got there by my own good sense, my good judgement, or because of natural laws, I don't feel gratitude. If I feel it's lucky that my baby survived or this leg got healed or that I made this trip safely. I feel gratitude. So I felt that the shrines were a display of gratitude. Isn't that beautiful?

TS:

Fantastic. It was an honour to meet you, and I am grateful! You have been very generous with your time. Thank you very much Professor Lingis.

AL: $\quad$ The honour is mine. 